\title{
Os sentidos do Lulismo: reforma gradual e pacto conservador. SINGER, André. São Paulo: Companhia das Letras, 2012, 280 p.
}

Patrícia Rocha Lemos ${ }^{1}$

"Os sentidos do Lulismo", de André Singer, é resultado da pesquisa apresentada parcialmente no artigo "Raízes sociais e ideológicas do lulismo", publicado em 2009, na revista Novos Estudos Cebrap, bem como de outros artigos. O livro, que combina dados empíricos com reflexões teóricas importantes, traz elementos para a difícil tarefa de explicar fenômenos ainda em curso. Acompanhando a trajetória de Singer, centrada nas preocupações com a democracia e a igualdade, o livro trata do período em que o autor esteve diretamente envolvido na campanha eleitoral e primeiro mandato de Lula.

O Lulismo é entendido pelo autor como "o encontro de uma liderança, a de Lula, com uma fração de classe, o subproletariado" e representaria o resultado de uma mudança chave na política brasileira: o realinhamento eleitoral que se cristaliza nas eleições presidenciais de 2006. Esse realinhamento, que consiste numa mudança fundamental do eleitorado, teria alterado a base do PT a partir do deslocamento da classe média em direção ao PSDB e da ocupação desse espaço pelo subproletariado, dando origem ao que o autor identificou como a "base lulista".

A conjuntura econômica mundial, as políticas de redução da pobreza - como o aumento do salário mínimo e do emprego formal, a ampliação do crédito e consequentemente do padrão de consumo,

${ }^{1}$ Mestranda do Programa de Pós-graduação em Ciência Política da Universidade Estadual de Campinas. E-mail: pat.rocha.lemos@gmail.com 
programas como bolsa família - e, ainda, a crise do 'mensalão', teriam sido o combustível desse realinhamento eleitoral e do surgimento do próprio Lulismo, acompanhado não na mesma medida, mas de significativas transformações do PT.

No primeiro capítulo do livro, André Singer discutirá as raízes sociais e ideológicas do lulismo. Inspirado na obra de Marx “O Dezoito Brumário de Luiz Bonaparte", Singer identifica algumas características do subproletariado com o campesinato francês. Aquela fração de classe, base do lulismo principalmente por conta da agenda de redução da pobreza, consiste assim num setor difícil de organizar porque tenderia a ser constituíd o politicamente de cima. No entanto, o lulismo teria sido capaz de realizar o programa dessa classe, confeccionando uma via ideológica própria a ela ao implementar o combate à pobreza a partir de uma autoridade capaz de "proteger os mais pobres sem ameaçar a instabilidade"(p.58). Por meio do bonapartismo ou cesarismo, argumento pouco desenvolvido no livro, teria se dado o aparecimento dessa base, possibilitando a implantação do modelo reformista fraco do segundo mandato.

Lula teria então optado por um caminho intermediário entre o neoliberalismo da década anterior e o reformismo forte que fora o programa do PT até as vésperas da campanha de 2002. Essa discussão programática aparece no segundo capítulo, intitulado "A segunda alma do partido dos trabalhadores", em que Singer sugere que os mandatos de Lula representaram uma síntese entre o que ele chama de "Espírito de Sion" - caráter radical, programático e de classe média - e a "alma do Anhembi" - defesa da ordem e o caráter crescentemente eleitoral e pragmático do Partido dos Trabalhadores.

No terceiro capítulo, "O sonho rooseveltiano do segundo mandato", Singer aponta na agenda do governo uma continuidade do modelo gestado no primeiro mandato, mas com maior margem de manobra e outra hierarquia de prioridades. Apesar de não ser comparável às transformações do New Deal, o Lulismo teria gerado 
redução da pobreza e garantido, a partir da busca de um ponto de equilíbrio para a manutenção da ordem, o atendimento de diferentes interesses de classe.

No capítulo final, Singer caracteriza o Lulismo como um reformismo fraco por entender que a política implementada consegue frear o neoliberalismo e apontar mudanças em relação ao atraso que mantinha a pobreza intocada. O autor mostra seu otimismo ao considerar que esse reformismo aponta para reformas estruturais caso o Lulismo se prolongue no tempo. A expectativa do autor é de que os próximos anos confirmem esse realinhamento eleitoral como um ciclo de longo prazo - a depender, claro, da margem nas condições econômicas do país.

"Os sentidos do Lulismo" têm impulsionado inúmeros debates sobre os governos do PT. Para além da polêmica sobre a força do realinhamento eleitoral e o questionamento a respeito de sua estabilidade e de seu caráter ideológico, destacaremos aqui alguns aspectos da discussão em torno das classes sociais e do seu papel nesse processo.

Nesse campo de debates, Singer converge com aqueles que desmistificam a ideia de que a classe $C$ teria formado uma "nova classe média". No entanto, a tese de que o subproletariado teria ascendido formando um novo proletariado, parece pouco desenvolvida e desconsidera o movimento de redistribuição no interior das classes trabalhadoras e médias que foi fundamental para a elevação da renda dos miseráveis.

Além disso, Singer explica o afastamento da classe média em relação ao PT pelo episódio do Mensalão, sem mostrar evidências de que essa seria a explicação para a aproximação com o PSDB. O autor também desconsidera as políticas que durante o governo Lula contribuíram para a precarização das condições de vida de setores da baixa classe média e dos trabalhadores a partir do sucateamento dos serviços públicos, aumento da terceirização e algumas medidas 
flexibilizantes, como o super simples, a lei de Falências e a Reforma da previdência de 2003. Por fim, o papel da burguesia passa à margem da análise - de modo que a "repolarização" entre pobres e ricos não coloca em discussão o papel da burguesia e de seus interesses na reprodução do lulismo.

Essa década de governos do PT, ou como diria Singer, de lulismo, analisada como um todo, parece mostrar a fragilidade do que ele chama de "Reformismo Fraco". Apesar de crítico, Singer é bastante otimista. Uma análise da distribuição do orçamento, da dívida pública e da política econômica já indica que políticas neoliberais têm ainda lugar na agenda do governo, ao passo que as políticas voltadas para a superação da pobreza devem continuar restritas à medida necessária para a reprodução eleitoral do "Espírito do Anhembi". Sobre os rumos do Lulismo, só o futuro dirá, mas as manifestações de junho no Brasil podem ser um sinal tanto de esgotamento desse modelo quanto de uma possível mudança na "alma conservadora" que Singer atribui ao subproletariado - talvez não tão orgânico ao lulismo como esperasse Singer. 